\title{
O PLANO, O CONTRAPLANO E O "PLANO SEM PLANO": IMAGENS OCIDENTAIS E MBYA GUARANI DAS RUÍNAS DE SÃO MIGUEL
}

Rodrigo Lacerda ${ }^{1}$

Em The Right to Look, Nicholas Mirzoeff (2011) resgata o termo "visuality"

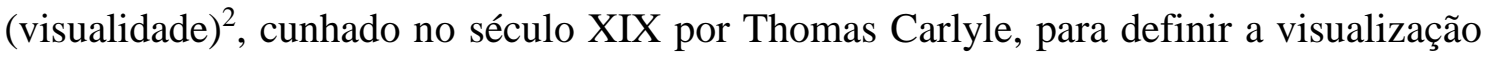
da História pelo poder colonial. Em primeiro lugar, a visualidade classifica, categoriza e define, isto é, constrói a realidade. Depois, segrega estes elementos em grupos de modo a prevenir que eles se estabeleçam enquanto sujeitos políticos. Por fim, aquela transforma a realidade assim construída em algo estético, quotidiano e naturalizado e a autoridade (o poder colonial) em liderança histórica. A visualidade não é apenas percetual, mas da ordem do imaginário, uma vez que articula elementos visuais, discursos e ideias. Nesse sentido, tal como outros autores advogam (Mitchell, 1986), neste artigo, a imagem não é apenas compreendida como uma representação visual, mas antes como uma "meshwork" (Ingold, 2012), isto é, uma malha de "coisas” fluidas e permeáveis, imersa em fluxos relacionados com discursos, ideias e a vida que são corporalizados em determinados momentos em diferentes meios (mental, paisagístico, museológico e audiovisual) (Belting, 2014).

Segundo Mirzoeff, a História é construída por conflito e, portanto, a visualidade é constantemente refutada pelos subalternos. Como argumenta Arjun Appadurai (2000: 6): "(...) it is in and through the imagination that modern citizens are disciplined and controlled by states, markets, and other powerful interests. But it is also the faculty through which collective patterns of dissent and new designs for collective life emerge." Isto é, a imaginação possibilita a construção da visualidade (o "plano" do Poder), mas também da contravisualidade (o "contraplano"). Um exemplo pertinente é a produção de media indígenas que têm sido utilizados para "talk back" e "shoot back" (Ginsburg, 1993) para a sociedade colonial com o objetivo de comunicar as histórias e culturas daqueles povos e corrigir preconceitos.

A categoria património estabelece linhas paralelas e imbricadas com o acima

\footnotetext{
${ }^{1}$ Faculdade de Ciências Sociais e Humanas da Universidade Nova de Lisboa (FCSH-NOVA); ISCTE Instituto Universitário de Lisboa (ISCTE-IUL); Centro em Rede de Investigação em Antropologia (CRIA), Portugal.

2 Trata-se, portanto, de uma interpretação e genealogia diferentes de outros estudos sobre visualidade (Foster, 1988).
} 
proposto. Por um lado, certos autores advogam que o património institucional, isto é, o património construído por organismos nacionais e transnacionais, é um instrumento de visualização da História pelo Estado-Nação e, portanto, de governamentalidade (Smith, 2006; Harrison, 2013). Por outro, aquela categoria também tem sido apropriada por grupos subalternos enquanto "contraplano", nomeadamente para questionar e expandir as narrativas nacionais, propor outras relações com o passado e memória e reivindicar a importância da cultura imaterial e não monumental (Ashworh, Graham, Turnbridge, 2007; Smith, Akagawa, 2009; Samuel, 2012; Cunha, Cesarino, 2014). Nesse sentido, o património é igualmente uma função do imaginário que se realiza ao nível de imagens mentais (isto é, alegorias [Gonçalves, 1996; Choay, 2014]), paisagísticas, museológicas (“cultural displays" [Dicks, 2003] ou "virtualidades" [Kirshenblatt-Gimblett, 1998]) e audiovisuais (Vidal, 2012; Waterton, Watson, 2016).

Porém, nem todas as imagens e patrimónios produzidas pelos subalternos são contraplanos, isto é, reações à visualidade construída pelo poder colonial. Por exemplo, a nível dos media indígenas, Jennifer Deger (2006) defende que a produção cinematográfica de comunidades aborígenes na Austrália encontra ressonâncias fenomenológicas com os modos nativos de conhecer e sentir o cosmo. De um modo paralelo, Rodney Harrison e Deborah Rose, que também têm trabalhado com coletivos indígenas naquele país, propõem uma ideia de património dialógica em que “(...) heritage making is interactive - meaningfulness arises out of encounter and dialogue among multiple subjects, some of whom are human" (Harrison, Rose, 2010: 264). Nesse sentido, recorrendo a uma citação relativa ao estudo de caso que se tornará mais clara à frente, proponho que certas imagens e patrimónios decoloniais, para além de existirem enquanto contraplano, são um "plano sem plano", ou seja, um vetor imanente de outras cosmologias e ontologias.

Tendo em conta esta contextualização teórica, neste artigo, examino, de um modo extenso, mas não exaustivo, as inúmeras patrimonializações das Missões JesuíticoGuarani, com especial enfoque na de São Miguel das Missões (RS), no sentido de compreender como aquelas foram construídas por diversos atores enquanto imagens (mentais, paisagísticas, museológicas e audiovisuais). Num primeiro momento, defendo que as Missões foram concebidas como alegoria da "utopia da civilização", isto é, enquanto empreitada da Companhia de Jesus que, supostamente, no fim do mundo, no 
meio de indígenas inocentes ou selvagens, conseguiu erguer uma civilização em termos físicos, sociais, económicos e espirituais. A partir do século $\mathrm{XX}$, a alegoria começou a transformar-se numa imagem paisagística, museológica e audiovisual através de intervenções nas estruturas e área limítrofe, construção do Museu das Missões e produção de espetáculos e filmes. Progressivamente, as apropriações patrimoniais populares e a historiografia oficial começaram a salientar a importância dos indígenas na organização cultural, social e económica das Missões (Langer, Jackson 1995; Soares, 1996; Neumann 2000, 2007; Souza, 2002; Ganson 2003). Ademais, o fim da Ditadura Militar e a Constituição de 1988 permitiram a emergência e a afirmação de várias identidades subalternas ao mesmo tempo que o turismo de massas (e, portanto, direcionado a diversas identidades) ganhou uma relevância crescente na economia do país e de pequenas localidades, como São Miguel. A conjugação de todos estes fatores propiciou, nas últimas duas décadas, uma transmutação da alegoria da "utopia da civilização", que, contudo, ainda persiste parcialmente, em imagens múltiplas e dissonantes de uma "utopia de encontro de culturas". Estas novas imagens compreendem as Missões como uma sociedade proto-multicultural em que indígenas e jesuítas colaboraram de um modo igualitário e harmonioso. Assim, enquanto a alegoria da "utopia da civilização" foi produto e produtor das narrativas de criação do Estado-Nação, as imagens da "utopia de encontro de culturas" contribuem para a construção do atual Estado plural ou multicultural - um "Brasil de todos", na terminologia dos governos de Luiz Inácio "Lula" da Silva. Contudo, no início deste século, devido a fatores associados a este movimento que serão aprofundados adiante, alguns Mbya Guarani começaram a realizar filmes que incluem reflexões sobre as ruínas de São Miguel e a sua história e situação colonial, isto é, que constituem um contraplano à produção imagética não indígena. Como veremos, estas outras imagens colocam problemas à gestão da dissonância inerente à categoria de património (Ashworth, Turnbridge, 1996; Smith, 2006). Ademais, este processo originou fricções e ressonâncias produtivas com o modo de ser deste povo que devemos compreender para além de uma mera "guerra de imagens" (Gruzinski, 2001). No mundo Guarani, as categorias património e cinema foram incorporadas nos vetores do bem viver e da bela caminhada para a Terra sem Mal que, recorrendo a uma expressão de um dos realizadores, podemos denominar de "plano sem plano". 


\section{Breve história das Missões Jesuítico-Guarani}

Segundo a historiografia ocidental, os remanescentes de São Miguel fazem parte das Missões Jesuítico-Guarani instituídas durante os séculos XVII e XVIII na Região Platina sob domínio espanhol. O objetivo destas estruturas era "civilizar" e catequizar os sujeitos indígenas no sentido de os assimilar nas populações do Império. Por outro lado, para os Guarani e demais povos reduzidos, as Missões eram um importante instrumento de defesa contra bandeirantes portugueses e outros inimigos.

Em 1750, Portugal e Espanha assinaram o Tratado de Madrid que determinou que o primeiro transferia a Colónia de Sacramento para o segundo em troca do território das setes Missões orientais. Os indígenas reduzidos não concordaram com esta decisão, enviaram uma carta para o rei de Espanha e, perante o impasse, iniciaram um conflito contra este país e Portugal que ficou conhecido como Guerra Guaranítica. Esta terminou em 1756 quando um dos mais importantes líderes Guarani, Sepé Tiaraju, foi assassinado e, três dias mais tarde, um exército sob o comando daqueles dois países dizimou um grupo estimado em 1500 Guarani. Na sequência de contendas europeias, os jesuítas foram expulsos de Portugal e das suas colónias, em 1759, e dos territórios espanhóis, em 1767.

Até recentemente, a historiografia defendia que, após este episódio, as Missões sob comando português tinham sido rapidamente abandonadas e que os restantes indígenas que viviam no território se tinham espalhado e misturado pela região, originando parte da população local. Porém, estudos recentes evidenciam que as Missões continuaram a ser utilizadas até meados do século XIX apesar de erros e limitações da administração portuguesa e, posteriormente, brasileira terem conduzido a uma rápida degradação das estruturas físicas e económicas (Sarreal 2014; Batista, 2015).

\section{Da alegoria da "utopia da civilização" à imagem da "utopia do encontro de culturas"}

Como supramencionado, num primeiro momento, as Missões Jesuítico-Guarani foram conceptualizadas enquanto alegorias de uma civilização utópica ${ }^{3}$ realizada na

\footnotetext{
${ }^{3}$ Por outro lado, as Missões também foram criticadas e conceptualizadas como distopias, especialmente no período que culminou com a expulsão da Companhia de Jesus de vários países da Europa. Num famoso panfleto anónimo, provavelmente escrito por Marquês de Pombal e difundido na Europa, o território das Missões era descrito como uma República Jesuíta que tinha o seu próprio Imperador, Nicolás I, que se sentava num trono, cunhava moeda própria e possuía um exército armado preparado para enfrentar Espanha
} 
terra. ${ }^{4}$ Por exemplo, Montesquieu, que, contudo, era crítico da Companhia de Jesus, escreveu em $O$ Espírito das Leis ${ }^{5}$ :

É glorioso para ela [Missões] ter sido a primeira que mostrou naquelas terras a idéia de religião unida à de humanidade. (...) e ela foi bem-sucedida. Retirou das florestas povos dispersos; deu-lhes subsistência garantida; vestiu-os: e, ainda que assim só tivesse aumentado a indústria entre os homens, já teria feito muito. (Montesquieu, 2000: 47-48)

Como em todas as utopias, as Missões eram descritas com o objetivo de construir uma imagem crítica da sociedade contemporânea dos autores e propor uma outra organização sociopolítica. Nesse sentido, a partir de meados do século XIX, aquelas estruturas foram equacionadas como protótipos de mundos por construir, isto é, enquanto sociedades proto-socialistas ou comunistas (Graham, 1901; Lafarge, 1915; Lugon, 1977; Callado, 1973). O exemplo mais conhecido é A República "Comunista” Cristã dos Guaranis, de Clovis Lugon, que nas primeiras páginas advoga:

A República Guarani era, sem dúvida, comunista demais para os cristãos burgueses e cristã demais para os comunistas da época burguesa. (...) ela nos aparece na História como a mais fervorosa das sociedades cristãs e a mais original das sociedades comunistas até à criação da União Soviética. (Lugon, 1977: 2)

$\mathrm{Na}$ década de 1920, têm início os primeiros processos institucionais de patrimonialização e, portanto, de (re)construção material das Missões enquanto "utopia da civilização". Em 1922, o Estado de Rio Grande do Sul classifica as ruínas de São Miguel como "lugar histórico" e três anos depois realiza obras de estabilização das estruturas (Meira, 2008). Em 1938, os remanescentes são um dos primeiros bens tombados pelo recém-criado Serviço do Patrimônio Histórico e Artístico Nacional (SPHAN). O processo foi conduzido pelo arquiteto Lúcio Costa que elaborou o relatório, apresentou propostas de conservação das estruturas e desenhou o futuro Museu das Missões que teria como objetivo albergar a estatuária e outros elementos da cultura material daquela época. O Museu constituiu um marco importante na reorganização imagética, uma vez que foi edificado no local em que começavam as primeiras casas indígenas, delimitando e reconstruindo no espaço a praça que existia em frente da catedral. Letícia Bauer (2006: 68) descreveu esta intervenção como “(...) a reordenação

\footnotetext{
e Portugal (Kern, 1994). Uma mistura das perspetivas utópicas e distópicas pode ser encontrada em alguns textos, como Cândido ou O Otimismo, de Voltaire (2016).

${ }^{4}$ Utopias e Missões Jesuíticas, de Arno Kern (1994), inclui uma análise detalhada e crítica das várias comparações entre as Missões e as narrativas utópicas.

${ }^{5}$ Montesquieu escreveu sobre as Missões antes da Guerra Guaranítica e da intensificação da propaganda contra os jesuítas na Europa.
} 
imaginária de Lúcio Costa”. Ana Meira acrescenta que:

[a]s grandes lacunas nos materiais construtivos podem ser um prejuízo para as ruínas, mas também podem tornar-se potencial, pois induzem à construção de uma narrativa. Lúcio Costa percebeu essas lacunas e sugeriu meios para estabelecer a narrativa, por meio de painéis, esquemas e mapas para que os visitantes compreendessem melhor a história das Missões. Além das narrativas escritas e desenhadas, utilizou-se de imagens construídas literalmente para demonstrar alguns elementos dessa narrativa, como das casas dos índios referenciadas na nova construção do Museu. Assim, dotou as ruínas da igreja de um contexto construído. (...) Lúcio Costa dá uma lição ao não perceber o monumento como objeto isolado. (...) A cruz missioneira, trazida de um cemitério em Santo Ângelo, ajudou a conferir caráter religioso ao lugar. (Meira, 2008: 341, itálico meu)

As razões do tombamento ainda são ambíguas. Segundo Márcia Chuva, além do barroco brasileiro de Minas Gerais, as Missões Jesuítico-Guarani foram uma das prioridades dos primeiros anos do SPHAN. A autora advoga que o tombamento destes elementos está associado à “(...) necessidade de reafirmação do fratricídio, visando a construção de uma genealogia da nação brasileira" (Chuva, 2009: 48). De facto, as ruínas estão situadas no Estado de Rio Grande do Sul que só foi realmente incorporado pelo Brasil no século XIX e que tinha, poucas décadas antes, atravessado disputas violentas internas (movimento de independência da Revolução de Farroupilha [1835-1845]) e externas (especialmente réplicas da Guerra do Paraguai).

Nesse sentido, o tombamento pode ser considerado uma maneira de "abrasileirar" o monumento e, consequentemente, o território. Por outro lado, é importante sublinhar que o relatório de Lúcio Costa tinha identificado as Missões como herança espanhola que constituíra “(...) um setor autônomo no conjunto dos monumentos coloniais brasileiros, verdadeira 'minoria' - a única, uma vez que os holandeses (...) pouco ou nada deixaram." (apud Meira, 2008: 243). Esta poderá ser uma explicação porque os remanescentes foram incluídos no Livro do Tombo das Belas Artes em vez do Livro do Tombo Histórico.

De qualquer modo, é importante não esquecer que o diretor do SPHAN, Rodrigo Melo Franco de Andrade, advogava que o património brasileiro não se limitava à exiguidade temporal e espacial do Brasil e que, pelo contrário, se estendia por milénios e três continentes, incluindo o património herdado das culturas indígenas e africanas e da “civilização" europeia (Gonçalves, 1996). Assim, os remanescentes podem ter sido compreendidos como parte desta última categoria em que a distinção entre Portugal e Espanha não é relevante. Por fim, Meira (2008) propõe ainda que o então ditador Getúlio 
Vargas tenha tido uma influência direta no processo, uma vez que ele era oriundo daquela região e, enquanto jovem deputado estadual, tinha sido um dos responsáveis pela criação, em 1921, da secção do Rio Grande do Sul do Instituto Histórico e Geográfico Brasileiro. ${ }^{6}$ Apesar de não ser possível chegar a uma conclusão definitiva sobre as razões do tombamento, o que é importante sublinhar nestes vários discursos é que, nesta fase, as Missões ainda eram imaginadas como uma obra monumental e utópica produzida exclusivamente pelos jesuítas, enquanto os Guarani eram considerados como simples e passivos recetores da arte e "civilização" europeias.

Paralelamente às patrimonializações institucionais do início do século XX, ocorreram diversos usos populares de elementos das Missões, principalmente por via da religião. Como supramencionado, Lúcio Costa tinha recomendado que todas as estátuas e santos missioneiros presentes na região fossem concentrados no Museu das Missões. Porém, muitos destes objetos tinham sido levados para casas particulares ou colocados em capelas comunitárias e, mais do que possuírem uma relevância pela sua origem, tinham ganho valores próprios associados à religião popular e à ideia de património familiar transmitido de geração em geração. O zelador das ruínas de São Miguel durante décadas, João Hugo Machado, foi um dos principais responsáveis por reunir as peças. Sempre que este sabia de informações sobre determinado santo, enviava uma carta ao diretor do SPHAN, que escrevia uma requisição polida a pedir o seu depósito no Museu. Frequentemente, este trâmite não era suficiente e Machado tinha de recorrer à intervenção opressiva da polícia ou a procedimentos ainda mais astuciosos (Bauer, 2006). Este processo foi extremamente controverso e ainda hoje está vivo na memória dos habitantes mais velhos da região (Silveira, 2004). Nesse sentido, podemos constatar que a imagem da "utopia da civilização" e a patrimonialização das ruínas não são um corolário inerente à experiência missioneira e que aqueles processos foram construídos por atores específicos com poder.

De um modo semelhante, a Romaria de Caaró, que teve início na década de 1920 e perdura até hoje, ilustra como certas apropriações populares podem ser subtilmente controladas por determinados agentes com objetivos particulares. A peregrinação celebra a morte dos padres Roque Gonzalez, Afonso Rodriguez e Juan de Castillos pelos

\footnotetext{
${ }^{6}$ A este nível, é, contudo, de realçar que a historiografia gaúcha de matriz lusa que se vinha consolidando desde os anos vinte excluía a influência indígena na formação do Estado de Rio Grande do Sul (Meira, 2008).
} 
indígenas no século XVII. Em 1933, foi determinado, a partir de supostas escavações arqueológicas realizadas por jesuítas, que os mártiros tinham ocorrido em Caaró, localizado a 14 quilómetros de São Miguel. No ano seguinte, os três padres foram beatificados e, em 1988, canonizados. Apesar do empenhamento popular, Júlio Ricardo Quevedo dos Santos (2014) sublinha que a construção de Caaró como "património cultural missioneiro" foi principalmente dirigida por intelectuais católicos, com destaque para elementos da Companhia de Jesus, com o objetivo de construir "narrativas positivas do martírio”. Em suma, mais uma vez, a romaria glorifica aquela ordem religiosa e o projeto utópico das Missões.

Sepé Tiaraju, um dos principais comandantes das tropas Guarani, ao qual é atribuído o grito "Esta terra tem dono!", também foi apropriado como herói por diversos movimentos religiosos e seculares. A nível das artes, ele foi mitificado, por exemplo, nos poemas O Uraguai (1769), de Basílio da Gama, e O Lunar de Sepé (1913), texto popular recolhido por João Simões Lopes Neto, e em músicas regionalistas. Paralelamente, Sepé transformou-se num santo popular na região e existem movimentos dentro da Igreja Católica, inspirados na Teologia da Libertação, no sentido de o canonizar. Além disso, têm ocorrido "canonizações" seculares. Em 2005, ele foi considerado Herói MissioneiroRiograndense, pela lei Estadual n 12.366, e, em 2009, Herói Brasileiro, pela lei nº 12.032, que determinou que o seu nome fosse incluído no Panteão da Pátria e da Liberdade Tancredo Neves, em Brasília.

A sua identidade é, contudo, liminar, porque, tal como as Missões, é discutido se aquele deve ser considerado indígena, espanhol ou percursor da população atual do Estado, enquanto as narrativas que enfatizam que ele nasceu com uma marca de lunar ou cruz na testa tentam representá-lo como cristão, colocando-o, assim, acima daquelas categorias. Devido a esta ambiguidade, o grito "Esta terra tem dono!" tem sido apropriado por diversos movimentos ideológicos, por vezes antagónicos, como o Movimento Sem Terra (MST), durante a Romaria da Terra (Aydos, 2004), e o movimento ruralista de São Gabriel (Brum, 2007) que, em oposição àquele, iguala a expressão à ideia de propriedade privada. Nesse sentido, Sepé é uma ponte entre a "utopia da civilização" e a "utopia do encontro de culturas". No primeiro caso, ele é considerado como um produto dos ensinamentos dos padres. No segundo, enquanto primeiro reconhecimento da agência dos indígenas na organização económica, social e política das Missões. 
Nas décadas seguintes à finalização do Museu das Missões, as obras de restauro e (re)construção da imagem da "utopia da civilização" continuaram. Em 1948, o SPHAN procedeu à limpeza da área em frente à catedral, reimaginando a praça que deveria ter existido na altura das Missões. Posteriormente, foram realizadas diversas escavações arqueológicas, incluindo em toda a área da igreja e casa dos padres que melhoraram a "visualização destes espaços" (Stello, 2017: 90) e revelaram os pisos originais. Na mesma altura, a área do sítio arqueológico foi expandida de quatro para vinte hectares. Em 1970, as ruínas dos povoados de São João, São Lourenço Mártir e São Nicolau foram incluídas no Livro do Tombo Histórico. Na década de 1970, o Instituto do Patrimônio Histórico e Artístico Nacional (IPHAN) proibiu o enterro de residentes dentro das ruínas, quebrando uma das últimas ligações físicas dos miguelinos às ruínas. Além de preocupações arqueológicas, era considerado que o cemitério prejudicava a imagem do espaço devido à utilização de certos materiais, como azulejos. Na década de 1980, a exposição do Museu foi modificada embora sem recorrer às novas perspetivas historiográficas que começavam a emergir e que reconheciam a influência indígena na organização social, cultural e económica das missões. O jesuíta continuou a ser o herói da "utopia da civilização".

Finalmente, em 1983, as ruínas de São Miguel foram classificadas pela UNESCO como Património da Humanidade, em conjunto com os remanescentes de San Ignacio Miní, Santa Ana, Nuestra Señora de Loreto e Santa Marí ala Mayor, localizados na Argentina. O relatório enviado pelo Ministério da Educação e Cultura do Brasil àquela instituição, em 1982, inclui uma única alínea (“cultural property”) na secção sobre a justificação da candidatura. Mais uma vez, esta assenta na contribuição da evangelização dos jesuítas para o desenvolvimento da "civilização" europeia naquela região do continente sulamericano:

\begin{abstract}
They [the Missions] are a precious testimony to European civilization, namely education, in the forests of the New World. The objetive of religious instruction of the Jesuit fathers found expression in the work of christianizing and educating the native inhabitants of the new continent known as America. This civilizing action of the disciples of Saint Ignatius of Loyola left a deep and lasting imprint on the social and cultural life of the population living in the ancient Jesuit State of Paraguay - a territory now divided into three countries. The ruins of Sao Miguel offer extremely rare examples of the distinctive architecture developed by the fathers in their villages and largely destroyed by the ravages of time and the negligence of man. Sao Miguel retains this rare and unique example of a Jesuit church with complete frontispiece and tower. (República Federativa do Brasil, 1982)
\end{abstract}

Paralelamente ao processo de construção alegórica, paisagística e museológica da 
"utopia da civilização", esta começou a ser imaginada em termos audiovisuais. Nos anos 1970, um médico de Rio Grande do Sul propôs à Secretaria do Turismo do Estado, que nessa altura apostava no desenvolvimento do turismo na região, a produção de um espetáculo de "Som e Luz" nos remanescentes de São Miguel que dramatizasse a "história" das missões. A ideia conseguiu cativar a participação de vários atores da Globo, inclusive Fernanda Montenegro, que cedeu a sua voz para corporalizar a catedral, e Lima Duarte, que personificou Sepé Tiaraju. O espetáculo continua até hoje, decorre à noite, tem a duração de pouco menos de uma hora e é constituído por um jogo de luzes de diversas cores e diálogos romantizados entre diferentes atores históricos. A catedral e, portanto, as Missões, é a narradora e é representada como a bela moça que todos cobiçam, enquanto as vozes masculinas de Sepé Tiaraju e do padre Antonio Sepp a defendem. O espetáculo foi recentemente remasterizado e há vontade da prefeitura em criar versões em inglês e espanhol, uma vez que o facto de aquele decorrer depois do pôr do sol leva a que muitos turistas pernoitem na vila, contribuindo, assim, para a economia local. Atualmente, a Superintendência do IPHAN no Rio Grande do Sul (IPHAN-RS) possui uma relação ambígua com o evento devido à sua inconsonância estética e histórica que coloca em causa o trabalho que tem desenvolvido na última década de atualização da narrativa histórica das Missões (ver adiante). Com esta intervenção, os remanescentes materializaram, pela primeira vez, o componente audio da sua imagem, pelo menos à noite, quando o passado mais facilmente nos assombra.

Em 1986, o cineasta britânico Roland Joffé estreou o filme The Mission (A Missão), que ganhou o prémio Palme d'Or no Festival de Cannes. A trama centra-se no fim das Missões e inclui os atores Jeremy Irons, padre jesuíta, e Roberto De Niro, mercenário convertido ao catolicismo, como heróis que enfrentam as personagens corruptas de Portugal, de Espanha e do Vaticano.

As Missões são representadas como espaços de harmonia e utopia em que a população indígena não possuiu agencialidade ou voz e é um dócil, feliz e exímio recetáculo da arte e "civilização" europeias. Como é comum ainda hoje no cinema ocidental, as falas dos indígenas não são traduzidas. Ironicamente, o realizador considerou a população Guarani contemporânea demasiado "aculturada" e decidiu contratar elementos de um povo indígena recentemente "contactado" na Colômbia (Ganson, 2003). Além disso, a obra inclui diversos erros históricos que, mais uma vez, 
roubam agência aos indígenas e glorificam os padres jesuítas.

Por exemplo, o filme culmina com a destruição de uma missão pelos exércitos de Portugal e Espanha em que os padres jesuítas, principalmente Jeremy Irons e Robert De Niro, o missionário e o ex-mercenário, encabeçam a luta inglória, enquanto homens, mulheres e crianças indígenas são dizimados. Segundo a historiografia ocidental, a principal batalha teve lugar em Caiboaté e não estiverem presentes menores ou elementos do sexo feminino. Além disso, não há indicação de que jesuítas tenham participado em batalhas contra os portugueses e espanhóis. Pelo contrário, alguns temeram pela sua vida porque tinham sido tomados como reféns pelos indígenas. Assim, mais uma vez, a experiência missioneira e os indígenas são utilizados enquanto alegoria, como o realizador explica em entrevista:

The Indians signify all kinds of things, but it's about the innocent. The Indians are innocent. The film is about what happens in the world ... what that innocence brings out in us. (...) What I wanted the story to be was two things: in one sense, as a modern metaphor for what is going on in Central America where the forces are exactly the same - a certain element of racism, commercial pressure, ideological struggle, the imperatives of commerce-with a much older story which is just a story of redemption and love. (apud Bird, 1987)

Um dos poucos contraplanos ocidentais à imagem da "utopia da civilização" é encontrado no documentário República Guarani (1981), de Sylvio Back. Nesta obra, o realizador brasileiro recorre a gravuras do tempo das Missões, excertos de um filme etnográfico, filmagens das ruínas e depoimentos de vários especialistas (incluindo Bartolomeu Meliá e Clovis Lugon) com o objetivo de construir uma "dramaturgia de entrevista" através da qual coloca em confronto diversas perspetivas que, sem buscar um veredicto absoluto, apresenta um olhar crítico sobre a empreitada da Companhia de Jesus. O início é exemplificativo desta abordagem. República Guarani começa com excertos silenciosos de um filme ${ }^{7}$ sobre o povo Xetá que foi quase totalmente aniquilado pelo avanço colonial nas décadas de 1950 e 1960 (Instituto Socioambiental, n.d.). Outras imagens do mesmo filme vão aparecendo ao longo da obra, indiciando que o realizador usa os trechos para aludir a um outro tempo, antes do "contacto" com a "civilização", mas também para chamar à atenção que o massacre físico e cultural continua no presente, através da colonização interna, evangelização e até da ação tutelar da FUNAI. Após estas

\footnotetext{
7 Xetá na Serra dos Dourados (1954)
} 
imagens e um longo travelling pela frente das ruínas de São Miguel (onde ainda se encontra um touro a pastar na relva), o filme introduz a primeira fala das entrevistas que serve de epígrafe e síntese da obra:

Em relação ao índio, a mentalidade colonial não mudou nada. O projeto colonial é o mesmo que o projeto atual. Talvez a única diferença seja que o desejo de integrá-lo à sociedade colonial criolla era que naquele momento o índio ainda representava uma força de trabalho notável. Hoje, tendo sido praticamente massacrados, eliminados, os índios não representam uma força quantitativa dentro das nações latino-americanas. Mas o projeto de assimilá-los, de integrá-los à "civilização" é o mesmo.

Na década de 1980, têm lugar ações de educação patrimonial em São Miguel dirigidas a turistas, à população local (com o intuito de restabelecer uma ligação desta com as ruínas) e a agentes do poder local (no sentido de estes compreenderem as limitações legais do património) (Moraes, 2014). Entre as diversas atividades realizadas incluem-se experiências de simulação de campo arqueológico com alunos do ensino fundamental, exposições, vídeos e cartilhas didáticas. Porém, como vimos, a população local tinha estabelecido ao longo do tempo diversas relações patrimoniais com as ruínas que foram progressivamente eliminadas pelo SPHAN/IPHAN com base em questões de preservação e conservação, realizadas por técnicos e políticos, muitas vezes distantes do local e em nome do suposto ulterior interesse da Nação ou da Humanidade. Nesse sentido, os programas educativos não pretenderam reviver ou revelar as antigas relações, mas sim estabelecer novas conexões baseadas no enquadramento do património institucional, isto é, tutelado pelo Estado. Como explica Luís Cláudio Silva, engenheiro florestal contratado pelo IPHAN para diretor do Museu das Missões no sentido de realizar esta mediação:

Porque o património histórico é o "não", não é? Não pode fazer nada. No Brasil, é. Tu não podes fazer, tu não podes reclamar (...) tu não podes mexer. É tua, mas não é tua. Eu cheguei para fazer essa aproximação. (...) Eu fui para lá e todo o trabalho foi feito nesse espírito. Esse trabalho de conquista das pessoas (...) Eu estava fazendo todo o trabalho ali, das pessoas do lugar reapropriarem os seus espaços. O espaço da horta era um espaço de património cultural. A dona Maria tinha uma horta no quintal. Não podia mexer, plantar, colher. Porque aquele espaço era espaço património cultural e não, não pode. Arrumar minha casa? Não pode. Nada pode. O que é que pode, afinal? Então, foi discutir isso, não é? Qual é que é o limite disso tudo. De que maneira é que conseguem se apropriar do espaço e ao mesmo tempo dar retorno e crescer. (...) Aí, os conflitos, óbvios, com prefeitos, com... Por uma questão: eles iam arrumar a sua cidade e não podiam. Mas não podiam porquê? Eles não entendiam porque não. A partir daí a gente começou a fazer cursos, informações. Levámos gente... Quando um grupo de prefeitos foi eleito, a primeira coisa que nós fizemos, foi o quê? Levámos para dentro da sacristia. Todos os novos prefeitos eleitos e a gente fez um curso. Dois, três dias. (...) A História é essa, as questões legais são essas. O que é que pode, o que é que não pode. (...) Receberam toda essa carga de informações e, depois disso, eles assinaram. Que eles estavam cientes daquilo. Então, a partir daí nós tivemos uma conversa diferente. Eles não podiam mais fazer coisas erradas dizendo que não sabiam. Eles podiam fazer coisas erradas mas eles já sabiam que não podiam fazer. 
Eles podiam fazer coisas certas, bastava conversar. Então se abriu um espaço para discutir isso. (Entrevista a Luís Cláudio Silva, 11 de abril de 2016)

Luís Cláudio Silva também ficou responsável pela expansão do entorno das ruínas, que incluiu a remoção de nove casas, clube social, posto policial e escola (hoje em dia, substituídas por relva e uma cortina de árvores que esconde as construções contemporâneas que ficaram) e originou diversas críticas entre os habitantes. Segundo Vladimir Stello (2013: 102), arquiteto do IPHAN em São Miguel das Missões na altura, esta ação permitia “(...) preservar parte dos vestígios arqueológicos da antiga redução e possibilitar uma boa leitura do núcleo principal da redução (...).” Além disso, foi iniciada a "reconstrução" (nunca concluída) da quinta jesuítica na parte de trás das ruínas que prenuncia a afirmação da imagem da "utopia do encontro de culturas", isto é, a construção de uma sociedade em que o indígena e o jesuíta aprenderam um com o outro em harmonia. O espaço devia incluir as plantas cultivadas pelos Guarani e aquelas trazidas pela Companhia de Jesus com o intuito de, como explica o antigo diretor do Museu, "caminhar no espaço e caminhar no tempo" e, assim, construir a narrativa do "(...) europeu, jesuíta, e o indígena se encontrando, gerando um novo conhecimento". ${ }^{8}$

Porém, nalgumas situações, a alegoria da "utopia da civilização" persiste e a imagem da "utopia do encontro de culturas" baseia-se em apropriações equivocadas de elementos indígenas, como o conceito Guarani de "Terra sem Mal" (Clastres, 1995). Este termo foi inscrito em diversos pontos de ónibus da localidade e aparece em guias dirigidos a turistas. Por exemplo, num dos dos livros mais vendidos na loja do Sítio Arqueológico, o conceito é incorretamente igualado à ideia de paraíso cristão:

As reduções, que tinham por finalidade primeira a catequese dos índios, muito se aproximaram da utopia ou sonho de uma Terra sem Males. Por meios pacíficos, os índios foram levados, conduzidos (reducere, do latim, redução), a viver numa sociedade que buscava a igualdade e a fraternidade cristã, talvez a melhor das experiências que a história registrou. (Dalcim, 2010: 8-9, itálico no original)

De qualquer modo, a imagem da "utopia do encontro de culturas" parece ser cada vez mais hegemónica. Por exemplo, Ana Meira, Superintende do IPHAN-RS entre 2003 e 2014, explicou-me que durante um seminário internacional da UNESCO, em Alhambra, organizado pelo Instituto Andaluz del Patrimonio Histórico (IAPH), que incluía apresentações de diversos monumentos notáveis do Património Mundial da Humanidade, a experiência das Missões provocou um impacto elevado na audiência por constituir uma

\footnotetext{
${ }^{8}$ Entrevista a Luís Cláudio Silva, 11 de abril de 2016
} 
imagem de uma sociedade proto-multicultural que poderia servir como exemplo para o mundo atual afundado em conflitos:

E aí começou o encontro e era assim: era a Grande Muralha da China, que tinha um milhão de visitantes por dia. (...) Stonehenge que tinha milhões... E tudo era mega, mega, mega. (...) E eu estava assim muito nervosa porque a gente não tinha o aparato técnico que os outros países tinham. Eles sabiam tudo dos patrimónios - quantas pessoas iam de manhã, de tarde e de noite; quantos eram crianças, quantos eram velhos; quanto de dinheiro movimentava; qual é a estrutura turística ao redor. A gente não sabe nada disso no Brasil. (...) E aí chegou a minha vez, não é? Aí quando eu olhei aquela plateia, assim, eram americanos ingleses, espanhóis, franceses... E um mês antes tinha começado a Guerra do Golfo, que estava aquela confusão, assim, os países envolvidos, enfim... E aí eu comecei por aí. Eu digo: “Olha, aqui nesse encontro tem muitos países que estão atualmente envolvidos no conflito pela incompreensão que existe entre culturas diferentes. E esse Património da Humanidade que a gente tem agora, ele pode ser um grande exemplo para a Humanidade no sentido da tolerância. E da negociação. Porque não podem existir dois povos tão diferentes que nem os Guarani e os jesuítas." (...) E eles conseguiram conviver durante 160 anos, não é? Claro que não devia ser fácil. Eu acho que isso que os antropólogos falam, "ah, porque os jesuítas vieram impor a sua..." Duas pessoas não iam conseguir impor nada para cinco mil, seis mil [indígenas], não é? É óbvio que aquilo era negociado e, enfim, eles conseguiram um equilíbrio ali (...). E aí eu comecei a falar nisso. Eles ficaram assim chocados. "O que vocês estão fazendo hoje no Iraque é uma coisa que seria impensável nas Missões.” Teve uns que se emocionaram assim, acho, meio que... Mas foi interessante. Eu acho que esse é um grande aprendizado para nós (...) acho que eles conseguiram uma experiência fantástica. (Entrevista a Ana Meira, 13 de abril de 2016)

Como podemos constatar, se a "utopia da civilização" servia a narrativa do Estado-Nação brasileiro até meados do século passado, a "utopia do encontro de culturas" funciona como símbolo para uma sociedade multicultural em construção. Nesse sentido, parece estar a ocorrer uma expansão desta última imagem com o intuito de incluir os diversos povos imigrantes que constituíram Rio Grande do Sul (apesar de, como é crónico neste Estado, ignorar os afrodescendentes). Por exemplo, no reverso de um folheto sobre a Rota das Missões ${ }^{9}$ é possível encontrar este texto:

Conheça a Rota Missões. Aqui você encontrará o local da realização da utopia do Cristianismo - A Terra sem Males. São atrativos ligados a história, a religião, a antropologia, a arqueologia, a culinária, aos espetáculos, as caminhadas e muito mais. Tudo em perfeita harmonia com a natureza e a cultura dos diversos povos que compõem o espaço, como os Guarani, os alemães, os poloneses e italianos compondo o tradicional gaúcho missioneiro.

No mesmo sentido, em 2002, foi estabelecido um termo de Cooperação Internacional entre o IPHAN-RS e o IAPH com o objetivo de aplicar o conceito de paisagem cultural à região missioneira que, além das reduções, incluiria as áreas

\footnotetext{
${ }^{9}$ Empresa que realiza diversos roteiros turísticos pelas Missões no Brasil, Argentina e Paraguai.
} 
transformadas pelos primeiros habitantes na pré-história, os lugares dos migrantes de origem europeia e as influências transversais dos atuais moradores da região. Stello (2013) trabalhou neste projeto e, na sua tese de doutoramento, argumentou que a categoria de paisagem cultural permite ultrapassar as limitações do património material e imaterial por possuir um caráter holístico, relacional e não focado num único elemento cultural. Nesse sentido, o autor propõe uma compreensão global da região, para além das Missões, que encontra paralelos com a ideia da "utopia do encontro de culturas":

Mas afinal qual é a Paisagem Missioneira? É uma paisagem onde os elementos se misturam e se sobrepõem, onde as pessoas com rasgos indígenas moram em comunidades de origem alemã, italiana ou polonesa, onde as pedras das antigas reduções aparecem ao lado de águas cristalinas ou muitas vezes barrentas da terra vermelha que as colore após uma "tenebrosa procela" - na expressão do Visconde de São Leopoldo -, fragmentos de um passado remoto, de um passado recente e até mesmo do presente, que se projeta para o futuro, que emolduram esta paisagem, que mais que ser uma realidade física, são as pessoas com seu jeito de ser que fazem a diferença. (2013: 222)

Contudo, a alegoria multicultural é mais estilhaçada e fractal. Já não é uma imagem tendencialmente única, gerida por um Estado que, apesar de também polvilhado de agências, encontra ou procura uma certa unicidade através de um enquadramento burocrático e técnico. Outras agencialidades, antes reprimidas, começam a conquistar autoridade e até, no caso do turismo, uma relevância institucional paralela (quiçá cada vez mais preponderante) (Marchi, Silva, Dezordi, 2015; Marchi, Costa, 2016). Um exemplo desta evolução é o "Ponto de Memória Missioneira", um espaço idiossincrático, construído neste século por agentes locais e situado perto das ruínas de São Miguel. O local inclui painéis interativos com animações e narrações datadas que, num estilo informativo supostamente neutro, ainda contam a história da "utopia da civilização". Por outro lado, o espaço acolhe diversos objetos relativos às Missões, mas também de outras culturas que habitaram e habitam aquela região. À entrada, uma placa esclarece que o acervo é constituído por elementos "Guarani, Cativos, Imigrantes, Revolucionários e Tradicionalistas" e que a avaliação dos visitantes considera que o espaço se caracteriza pelo “(...) espírito missioneiro, uma miscigenação de cultura que é capaz de mediar o bem palpável ao espiritual..."

Por fim, a obra artística "Jaz", de João Loureiro, ${ }^{10}$ é um possível contraplano não

${ }^{10} \mathrm{O}$ trabalho tem origem num edital de Arte e Património lançado em 2007 pelo IPHAN e Ministério da Cultura, com o patrocínio da Petrobrás, que tinha como objetivo estabelecer diálogos entre as artes visuais 
indígena. $\mathrm{O}$ trabalho é constituído por uma escultura de uma cabeça grande de um bandeirante, ${ }^{11}$ enterrada no solo, protegida por um vidro e acessível por uma escada (Benetti, n.d.). A criação pode ser interpretada de diversas maneiras. Num primeiro momento, é possível argumentar que a obra critica a ideia de narração da história na modernidade através da monumentalidade (Riegl, 2013). Por outro lado, o trabalho pode ser compreendido como um perscrutar do inconsciente da região e da Nação que ainda é dominado pela mentalidade colonial, do qual o bandeirante é um importante símbolo. Trata-se portanto de um contraplano subtil que, como é expectável, não foi bem aceite. A obra foi aprovada pelo IPHAN central, mas não foi acolhida com agrado pela Superintendência do Estado nem pelo departamento local, que advogaram que aquela não podia ser colocada no Sítio Arqueológico por questões técnico-científicas (mas, provavelmente, também devido à questão imagética em análise neste artigo). Assim, acabaram por a enterrar num espaço relativamente distante e de difícil acesso. Hoje em dia, encontra-se abandonada e deteriorada e a maioria dos miguelinos desconhece-a.

Em síntese, nas últimas duas décadas, a imagem de "utopia da civilização" começou a transformar-se, de um modo ainda frágil e múltiplo, em imagens de "utopia de encontro de culturas" em que indígenas e jesuítas aprenderam uns com os outros e construíram uma sociedade proto-multicultural. A maioria das imagens é positiva, agradável e ignora as relações de poder constitutivas do colonialismo. Contudo, até agora só analisámos os atores não indígenas. No início do século, alguns Mbya Guarani começaram a realizar filmes sobre as ruínas de São Miguel e, portanto, a envolver-se na construção visual daquelas estruturas. Quais foram as imagens produzidas por este povo e em que sentido estas constituem um contraplano?

\section{Os Guarani que nunca partiram}

Dados recentes indicam que os Guarani nunca abandonaram a região e que a continuaram a percorrer em pequenos grupos, visitando com frequência as ruínas (Souza, 1998; Moraes 2010). Contudo, a presença atual deste povo em São Miguel tem origem

contemporâneas e o património artístico e histórico nacional. Outras obras podem ser consultadas em www.artepatrimoniorg.br.

${ }^{11}$ Alusivo, em termos conceptuais e estéticos, ao Monumento às Bandeiras, construído em 1954 para assinalar os 400 anos de fundação de São Paulo e localizado à entrada do Parque do Ibirapuera, nesta cidade. 
nos anos 1990, quando duas carrinhas da cidade de Tupanciretã (RS) deixaram um grupo de Mbya em São Miguel com o argumento que "lugar de índio é nas Missões". O diretor do Museu das Missões, Luís Cláudio Silva, disponibilizou o espaço da Fonte Jesuítica para eles acamparem e o prefeito providenciou cesta básica, apoio de saúde e outras ajudas. Segundo aquele, o prefeito considerava “(...) que as ruínas por si só não bastavam. Que àquela história faltava um elemento, que são os índios". Gradualmente, o acampamento transformou-se num ponto de passagem nas rotas de mobilidade (Garlet, 1997) ou multilocalidade (Pissolato, 2007) dos Mbya-Guarani. Alguns começaram a comercializar artesanato como fonte de renda na entrada do Sítio Arqueológico e o diretor acabou por os convidar para o interior. Como este explica:

Eles estavam vendendo ali na frente, ali fora. Eles ficavam numa situação, no tempo, ao relento... (...) Os turistas chegavam, desciam no estacionamento e iam para dentro, visitar e depois iam embora. (...) Aí, o que é que a gente começou a ver? Que as pessoas não queriam simplesmente comprar o artesanato, elas queriam comprar uma lembrança de um momento em que esteve com um índio de verdade. Então, na realidade, essa era a lógica. Quer dizer, eu materializo no artesanato, numa coisa que eu compro, o momento que eu tive. (Entrevista a Luís Cláudio Silva, 11 de abril de 2016)

Nesse sentido, apesar das boas intenções do diretor, a introdução dos Guarani no Sítio Arqueológico pode ser compreendida como mais uma etapa do processo de construir uma imagem do passado em que se ocorre a uma valorização de determinados componentes materiais através da inclusão de elementos humanos, étnicos e imateriais na virtualidade do património (Kirshenblatt-Gimblet, 1998). Por outro lado, esta ação encontrou resistência por parte do IPHAN-RS e central que continuavam dominados pela alegoria da "utopia da civilização", pela ideia de que aqueles Guarani não eram descendentes dos indígenas das Missões e por arquitetos que privilegiam a lógica da conservação. Segundo Luís Cláudio Silva:

Eles não podiam fazer coisas lá dentro. Com a separação dessa coisa que é o património, esse construído... Como se os índios não fizessem parte daquilo. Eles eram considerados tipo a escória da sociedade. O que não deveria estar lá. (...) $\mathrm{Na}$ época das reduções eram três padres jesuítas europeus e sete mil índios. Afinal esse património é de quem? Não é? Se é património da Humanidade, ele está num território muito claro. Bom, ele está dentro do Brasil, mas está dentro do Rio Grande do Sul, mas ele está dentro de um território que é indígena. Na origem. (Entrevista a Luís Cláudio Silva, 11 de abril de 2016)

Os Guarani e aliados começaram a trabalhar em diversos projetos para captar recursos e apoiar a presença indígena na cidade, nomeadamente no sentido de demarcarem áreas indígenas. Em 1999, o Estado do Rio Grande do Sul elegeu Olívio 
Dutra como governador e este encetou uma política de compra de terras para usufruto de populações indígenas. No ano seguinte, o Estado adquiriu um terreno de 236 hectares, a 30 quilómetros das ruínas, que deu origem à Reserva Indígena Inhacapetum e à aldeia Tekoa Koenju. Esta área é demasiado exígua para os Guarani viverem o seu modo de vida e, por isso, continuam a vender artesanato no alpendre do Museu das Missões como fonte de renda. Devido à distância, os Mbya apanham um ônibus da aldeia na terça-feira de manhã, pernoitam numa casa com condições precárias na parte de trás do Sítio Arqueológico e regressam a Koenju no sábado à tarde.

\section{O contraplano: Mokoi Tekoá Petei Jeguatá, Duas Aldeias, Uma Caminhada}

No ano 2000, três anos antes da aprovação da Convenção da UNESCO para a Salvaguarda do Património Imaterial, o Brasil criou o Programa Nacional do Patrimônio Imaterial que instituiu o Registro de Bens Culturais de Natureza Imaterial e o Inventário Nacional de Referências Culturais (INRC) como metodologia de mapeamento daqueles bens. Devido à confluência de diversos fatores que não é possível explicitar aqui, o IPHAN-RS iniciou em 2004 a aplicação do INRC junto da população Mbya-Guarani acima mencionada. Este projeto foi produto e produtor de uma nova atitude do Instituto que, no mesmo período, encetou uma revisão da exposição do Museu das Missões no sentido de incluir a contribuição indígena na organização socioeconómica das reduções.

Durante a aplicação do INRC, algumas lideranças Guarani expressaram interesse em receber formação em realização de filmes e, nesse sentido, o IPHAN-RS contratou a ONG Vídeo nas Aldeias (VNA) que há trinta anos desenvolve trabalho colaborativo com povos indígenas na área do audiovisual e que, desde 1997, organiza oficinas de formação de cineastas em aldeias indígenas. A primeira oficina decorreu em 2007 nas aldeias Anhenteguá, perto de Porto Alegre (RS), e em Koenju. Esta experiência intensa gerou mais de 100 horas de filmagem e resultou no documentário Mokoi Tekoá Petei Jeguatá, Duas Aldeias, Uma Caminhada (2008), com direção dos Mbya-Guarani Ariel Duarte Ortega, Jorge Ramos Morinico e Germano Beñites.

A segunda parte de Mokoi Tekoá decorre em Koenju e nas ruínas de São Miguel. A sequência começa com Mariano, personagem escolhido por Ariel para acompanhar neste espaço, que sai de dentro de sua casa, ainda meio estremunhado e iluminado pela 
luz dourada do alvorecer, lava a cara e prepara o mate (ka'ay). A seguir, verifica as armadilhas de caça e, ao constatar que não apanhou nada, comenta, num misto de desalento e revolta: "Tem muito pouco tatu, por isso não cai. (...) Quando tinha mata, a gente não só olhava mas pegava. (...) Assim não dá. A gente tinha que ter mais matas. Perdi o meu milho e na mata não pego nada. Então agora, tem que fazer cesto para vender." Como corolário desta situação, nos planos seguintes, o filme acompanha diversos Guarani a produzir artesanato, como cestas (ajaka) e bichinhos (vicho ra'anga ${ }^{12}$, para vender no Sítio Arqueológico.

Ao contrário de certos registros etnográficos clássicos, Mokoi Tekoá não dá especial atenção às diversas etapas de produção de artesanato. Pelo contrário, o filme centra-se nos diálogos que ocorrem durante o trabalho e que incluem discussões sobre os materiais e técnicas utilizadas, mas, principalmente, interlocuções sobre a cosmologia Guarani e a sua situação colonial. Neste contexto, o tema da relação com os turistas que compram o artesanato nas ruínas surge com frequência misturado com o sentido de humor ameríndio (Overing, Passes, 2010) e a circulação constante do mate ( $k a$ 'ay). Por exemplo, enquanto uma Guarani conclui um cesto grande, outros provocam-na num espírito de alegre picardia:

- Por quanto vai vender?

- Por quanto?...

- Por quantozinho?...

- Por 5.

- Não, por 10.

- É, porque você só sabe falar "cinco reais"!

- Eita ferro.

- Coisa grande você vende por cinco!

- É mais fácil de falar né?

- É mesmo.

- É só o que ela sabe.

- Dizer "cinco" é mais fácil.

- Cinco, cinco, cinco.

É, contudo, de sublinhar que a situação colonial é compreendida segundo a mentalidade da modernidade, mas também da cosmologia Guarani. Um dos exemplos

\footnotetext{
12 Miniaturas em madeira da fauna nativa.
} 
mais contundentes é a seguinte fala de uma artesã: "Os deuses já sabiam que a gente ia precisar vender artesanato, que as matas iam se acabar... Então por isso os deuses nos deram essa habilidade de seduzir os brancos com os bichinhos de madeira. Pra vender e não morrer de fome." Este discurso demonstra como os Guarani são deterministas (Schaden, 1974) e consideram que os deuses cuidam dos seus filhos apesar das provações da terra imperfeita em que vivem. Além disso, a ideia de "sedução" permite equacionar a produção de artesanato como uma "tecnologia de encantamento" (Gell, 1998) com o intuito de capturar (o dinheiro de) os brancos (Assis, 2006).

Após quinze minutos em Koenju, Mokoi Tekoá continua nas ruínas de São Miguel onde o tema do artesanato é desenvolvido em termos da sua etapa final - a venda. A primeira sequência é construída de um modo que se assemelha a uma cena de guerra ou, mais especificamente, de invasão (dos brancos). Num plano muito geral vemos, ao longe, a catedral e alguns turistas com poucos pixéis de altura. Entretanto, de detrás da câmara, entram em campo vários alunos que, devido à perspetiva contrapicada e à relação de escala com as ruínas, parecem gigantes.

Uma das meninas fala para um menino mais novo: "Flecha? Sabe quanto? Dez reais!" O exército de alunos afasta-se em direção às ruínas. Em contraplano, duas personagens Guarani dispõem o artesanato nas mantas (isto é, preparam-se para o embate) e discutem os preços. A seguir, vão sendo introduzidas sequências de interação entre os Mbya e os turistas que demonstram uma tensão crescente até atingirem um clímax. Num primeiro momento, as perguntas são um pouco exasperantes, mas os Guarani parecem já estar habituados.

Turista: É utilizado para alguma coisa ou é só para...

Guarani: É só para brincar.

Turista: É só para brincar. A mesma coisa a flecha?

Guarani: É.

Turista: E vocês ainda caçam com flecha assim de verdade ou não?

Guarani: Agora não.

Turista: Não? [A turista afasta-se sem comprar nada.]

Mais tarde, a relação dos turistas com os Guarani torna-se mais penosa. Uma montagem rápida corta entre diversos não indígenas a fotografar os Guarani e uma mulher que 
irrompe cheia de energia pelo alpendre do museu a perguntar:

Turista: Bora tirar uma foto com a senhora [Guarani que vende artesanato]?

Guarani [timidamente e quase inaudível]: Não.

Turista [esbracejando em várias direções]: Ah não! Não quer. Eu queria tanto! Qual é a origem de vocês? Tupi? Guarani?

Logo a seguir, um Mbya diz em guarani: "Comprem, não fiquem só tirando foto. Vocês não compram nada, só ficam tirando foto", enquanto uma professora e vários alunos com câmara fotográfica rodeiam a sua esposa no chão com uma filha e o artesanato. $\mathrm{O}$ homem afasta-se, mas a professora decide segui-lo, quase persegui-lo, inquirindo insistentemente: "Vocês são da onde? Daqui mesmo? Vocês moram aqui mesmo? Sim? São Guaranis?” O Guarani vai respondendo a contragosto e entredentes. Esta sequência culmina com a altercação entre um professor de História e Ariel em que aquele acusa os indígenas de um comércio com a imagem e o realizador chama à atenção que o seu povo está farto de ver a sua imagem ser explorada sem renumeração.

A certa altura, Mokoi Tekoá produz uma crítica subtil ao justapor a venda de artesanato contemporâneo e as obras de arte jesuítico-guarani expostas dentro do Museu das Missões. Primeiro, um plano filmado a partir do interior deste mostra, através das paredes de vidro do edifício, três meninas não indígenas a comprarem um brinco com penas a uma Mbya-Guarani. A seguir, o filme corta para uma placa do Museu que indica "Favor não tocar nas imagens" e, num movimento de câmara suave, revela uma estátua produzida pelos Guarani no tempo das Missões. Assim, sinteticamente, a montagem confronta o valor e estatuto conferido pelo mundo ocidental à arte produzida pelos Guarani contemporâneos (o artesanato) e à arte produzida pelos Guarani no tempo das Missões ("segundo os ensinamentos dos Jesuítas", uma vez que a exposição ainda se insere na alegoria da "utopia da civilização"). A primeira encontra-se "fora" (do espaço museológico), é regateada pelos turistas e a sua autenticidade é questionada ("É só para brincar.”). A segunda é exposta “dentro" do espaço do Museu e das categoria autónomas de "arte" e património (não pode ser tocada e não tem valor monetário porque possui um valor simbólico incomensurável) e é usada como um dos fundamentos da imagem da "utopia da civilização".

Esta crítica está relacionada com outra questão abordada por Mokoi Tekoá: a 
diferente valorização do "Guarani histórico" e do Guarani contemporâneo. Como argumenta Ariel a certa altura: “Os Guarani foram os protagonistas dessa história. Mas agora eles estão ali daquele jeito. A morte deles só tem valor na História... Ainda existimos, e os turistas veem os Guarani tentando vender no museu. Essa é a nossa realidade.” O filme é exemplar a demonstrar esta situação. Os Guarani contemporâneos são apenas vistos como fantasmas da História, como remanescentes. Os turistas comercializam com eles, mas não os veem como atores históricos. O parque arqueológico permite que os Guarani vendam artesanato, mas não faz quase nenhuma menção à sua existência atual (situação recentemente alterada através do processo do INRC). Os guias turísticos contam a história, mas ignoram o presente. Em suma, existe um fosso abissal entre os dois tempos que, implicitamente, nega a continuação cultural, histórica e identitária entre os Guarani do passado e do presente.

Esta clivagem assenta em diversos pressupostos e problemas de compreensão intermundos. Um dos mais perniciosos e que é destacado pelo filme é o fantasma profundamente enraizado (inclusive até, recentemente, na antropologia [Schaden, 1974]) que os Guarani são um povo "aculturado". Apesar de entretanto invalidado pelas ciências sociais, o modelo da aculturação persiste no senso comum (Cesarino, 2008). No contexto de venda de artesanato, esta questão associa-se também ao tema da autenticidade dos objetos, como, por exemplo, quando perguntam, com uma gravidade nostálgica, se o arco e flecha ainda são usados para caçar.

Assim, no olhar pesado e romântico dos turistas "modernos", é possível ler o seguinte raciocínio: os Guarani já não caçam e, portanto, eles e a sua arte já não são autênticos. Esta situação é especialmente dolorosa para os Guarani porque assenta no paradoxo, exemplificado pela primeira fala de Mariano, de que eles já não podem caçar devido à situação colonial produzida pelos não indígenas que os criticam por não caçarem mais.

De qualquer maneira, o discurso da "aculturação" acaba por ter um efeito nefasto no sentimento identitário dos Guarani. Por exemplo, numa preleção incluída no início do filme, um Guarani mais velho enuncia: "É verdade que hoje estamos quase dominados pelos brancos. Mesmo assim não podemos esquecer a nossa cultura. Não podemos nos esquecer de tudo. Como os próprios brancos dizem: 'Não troquem a sua cultura pela nossa!'” Outros, contudo, parecem considerar a ideia meramente absurda, como num 
diálogo entre três Mbya registado em Koenju:

- Estão dizendo que os índios não plantam.

- É, estão dizendo isso.

- Não plantam e estão esquecendo da sua cultura. Isso é o que dizem os brancos.

- Não esquecemos.

- É mesmo, não esquecemos. Temos TV, mas nem por isso estamos como os brancos! [risos] Que loucura!

Numa outra sequência, a ideia de autenticidade é criticada e colocada em oposição à agenda também ocidental do "meio ambiente". No final do dia, Patrícia conta a Ariel que "[u]m branco perguntou porque os artesanatos eram caros. Perguntou se era pena de pássaro mesmo. (...) Quando eu falei que era só pena de galinha pintada, ele riu e falou: 'Então não vou comprar."” Ariel responde com um sorriso desafiante: "Por que você não perguntou se era pra sair matando passarinho só pra vender?” Em suma, apesar do discurso "aculturação"/"perda de cultura" poder influenciar os Mbya, eles possuem uma posição crítica, subversiva e autónoma em relação àquele.

Mokoi Tekoá termina com a partida dos turistas e os Mbya a arrumarem o artesanato que não venderam. Em jeito de conclusão, mas também colocando uma questão que irá suscitar a continuação do INRC e dos filmes seguintes, Ariel comenta:

Hoje eu percebi o que acontece aqui. É chocante mesmo. Experimenta vir sem vender e só ficar observando. Aí você vai ver como o rosto dos Mbya muda. (...) A gente não fica triste só porque não vende, é porque parece que a gente depende do dinheiro deles, que se eles não compram a gente morre de fome. Alguns também falam: "Por que vocês ficam aqui, onde mataram os seus antepassados?"

Paralelamente às sequências sobre artesanato, o filme alterna entre quadros sobre a história ocidental das Missões narrados por guias turísticos e, em contraplano, descrições sobre a violência desses tempos expostos pela voz de Mariano e outro Guarani. O oficineiro do VNA, Ernesto Ignácio de Carvalho explica que a receção das pessoas da aldeia às filmagens das narrativas dos guias foi dolorosa:

É difícil assistir àquele material, por que por mais que estejam bem intencionadas e por mais que os Guarani já tenham escutado aquilo repetidas vezes, na edição, a cena revela o momento de encontro de um discurso sobre eles que é uma simplificação histórica extremamente violenta. Acho que é doloroso para as pessoas ficarem escutando aquela versão reduzida da história delas. Elas ficavam agoniadas. (apud Carvalho et al, 2011: 147)

As falas dos guias incluídas no filme são profundamente reveladoras da imagem 
produzida pela sociedade colonial sobre os Guarani, especialmente através da alegoria da "utopia da civilização": os Guarani (do tempo das Missões) são descritos como crianças dóceis, curiosas, sem agência e não preparados para o trabalho, enquanto os jesuítas são representados como heróis que tiveram a dupla missão de "salvar" os indígenas dos bandeirantes e deles próprios através da evangelização e da "civilização".

Em contraplano, Mariano apresenta uma narrativa distinta. Logo no início da sequência nas ruínas, a câmara acompanha-o de manhã a chegar ao local enquanto explica:

Por aqui andaram os nossos parentes. Mas os brancos tiraram tudo da gente, e se apropriaram dessas ruínas que nossos parentes fizeram. Agora eles não querem dar pra gente o que é nosso. Eles têm ciúmes desse espaço. Nossos parentes construíram isso forçados pelos brancos, os padres Jesuítas. Eles forçaram os índios a trabalhar nisso.

Mais à frente, Mariano acrescenta:

(...) nossos parentes sofreram muito. Nossos parentes, trabalharam, enfrentaram sofrimento, pra deixar isso aqui na terra. Deixaram isso, e trabalharam tanto para que depois os brancos os matassem todos. Os brancos brigaram por causa disso aqui. Até das crianças eles cortavam os pescoços, foi assim. Os brancos fizeram isso com nossos parentes. Tudo isso é doloroso pra nós. Se pensarmos, dói até hoje.

Assim, em contraplano à historiografia oficial dos guias, Mariano explica que as ruínas foram construídas pelos Guarani e que os brancos foram principalmente agentes de ciúme, roubo, violência e morte. Nesse sentido, os remanescentes de São Miguel não são só um património dissonante (Ashworth, Turnbridge, 1996; Smith, 2006), mas são, acima de tudo, um palco de violência colonial que sintetiza, corporaliza e visualiza a ferida colonial (Mignolo, 2012) dos Guarani no passado e no presente. Em primeiro lugar, não foi só São Miguel que foi expropriado aos Guarani. Todo o seu território foi tomado pelos jurua (não indígenas) e eles foram jogados para bermas de estrada e reservas e terras indígenas diminutas.

Nestas áreas é quase impossível viver segundo os preceitos dos deuses Nhanderu ou mesmo obter uma subsistência mínima. Consequentemente, os Mbya são obrigados a produzir artesanato para vender àqueles que são responsáveis pela usurpação da sua terra. Em segundo lugar, os Guarani que interessam aos jurua, à História e ao Património, são os Guarani do passado. Os atuais são desprezados e considerados como tendo atravessado um suposto processo de aculturação de indígenas a indigentes.

Este confronto extremamente desigual é avaliado pelos não indígenas segundo a 
sua perspetiva e cultura e, assim, como diz o professor de História que aparece no filme, os Mbya são considerados sujos, pedintes, etc. A esta situação acresce a espoliação não só das ruínas, mas de vários elementos cosmológicos dos Guarani - como o conceito de Terra sem Mal, Sepé Tiaraju, o chimarrão, etc. - que são reassemblados para construir a identidade gaúcha, do Estado de Rio Grande do Sul, do Brasil ou de vários movimentos sociais. Além disso, em São Miguel e Santo Ângelo existem dentistas, hotéis, ônibus, etc. com o nome de Missões ou de Sepé Tiaraju, constituindo uma saturação patrimonial, mas também uma espécie de cerco patrimonial que rodeia e asfixia os Guarani. Isto é, não se trata apenas da incorreção que os Guarani só existiram no passado, é o erro de considerar que o colonialismo só existiu no passado.

O colonialismo perdura hoje e o Sítio Arqueológico de São Miguel é um dos palcos mais visíveis desta situação. Por fim, - e começamos a entrar em ontologias diferentes sobre o património - para os Guarani, o passado e o presente não são necessariamente temporalidades distintas e estanques. As ruínas não são um "teatro da memória" (Samuel, 2012) porque, como Mariano demonstra, a violência e a submissão que os Guarani sofreram no tempo dos jesuítas não faz apenas parte da dimensão da memória coletiva, mas encontra-se viva e corporalizada nos remanescentes. Enquanto que a mentalidade da modernidade objetiva as subjetividades, as ontologias ameríndias tendem a subjetivar os objetos (Viveiros de Castro, 2015), e, nesse sentido, ao contrário daquela, para os Guarani é o intangível que engloba o tangível (Byrne, 2014). Assim, não é a memória de um passado, mas o corpo ferido de um passado no presente.

\section{Um plano sem plano: Tava, A Casa de Pedra}

Porém, a história não acaba aqui. Como Ariel menciona no final de Mokoi Tekoá: "Por que vocês ficam aqui, onde mataram os seus antepassados?" Durante a pesquisa do INRC, a equipa de antropólogos descobriu que os Guarani possuem um nome específico para as ruínas - tava - que quer dizer casa ou aldeia de pedra e que aquelas constituem uma ontologia diferente da do mundo ocidental. Em 2007, o IPHAN organizou uma reunião em São Miguel que juntou diversas lideranças Guarani para discutir os resultados do INRC e decidir qual deveria ser o bem registrado enquanto património imaterial deste povo. Como corolário daquelas questões ontológicas e das fricções políticas evidenciadas em Mokoi Tekoá e em outras arenas (Moraes, 2010), doze lideranças Mbya do Brasil e da 
Argentina encaminharam um pedido de registro das ruínas de São Miguel enquanto património imaterial.

A equipe do INRC centrou a pesquisa neste aspeto, mas encontrou ainda mais dificuldades em obter informações junto dos Guarani do que nas etapas anteriores. Neste contexto, o IPHAN-RS voltou a contratar o VNA no sentido de estes produzirem o filme de documentação que também foi parte constitutiva e essencial da pesquisa. $O$ trabalho final, Tava, A Casa de Pedra (2012), é assinado pelos não indígenas Vincent Carelli e Ernesto Carvalho e pelos Mbya-Guarani Ariel Duarte Ortega e Patrícia Ferreira (professora indígena e companheira de Ariel). Enquanto os documentários anteriores assentavam numa abordagem de cinema direto, Tava está principalmente estruturado através de entrevistas com velhos de aldeias do Rio Grande do Sul, São Paulo, Rio de Janeiro e Argentina. A participação de Ariel foi fundamental porque, além de ser um Guarani carismático que sabe ouvir e falar com os mais velhos, também é neto de um dos mais importantes caciques da Argentina que todos os Mbya conhecem. Sem dúvida, este foi um cartão de visita fundamental para obter os vários depoimentos sobre as ruínas que eram largamente desconhecidos dos não indígenas e até de uma parte significativa dos Guarani. Como corolário deste processo, as ruínas de São Miguel foram registradas enquanto património cultural imaterial Tava, Lugar de Referência para o Povo Guarani, pelo IPHAN, em 2014.

O filme Tava dá voz a diferentes imagens Mbya sobre as ruínas, distintas da historiografia ocidental, mantendo o ponto de vista pessoal do enunciador e sem pretender construir uma versão generalizada e canónica. Por outro lado, a perspetiva ocidental é pontualmente apresentada através da imagem patrimonial, descorporalizada, imponente e pretensamente objetiva do espetáculo de Som e Luz e do filme The Mission. Apesar da dissonância, o documentário demonstra que a tava é um património cultural para os Guarani porque se trata de um local onde viveram os seus antepassados a caminho da $Y v y$ Mara ẽy (Terra sem Mal) na qual se transformaram em seres imperecíveis (Nhanderu Mirim). Nesse sentido, viver e visitar as ruínas faz parte do vetor mais importante da vida dos Mbya - o nhande reko (nosso modo de ser) que é constituído por diversas práticas estético-éticas de convivialidade, comensalidade e corporalidade que têm como objetivo transcender a condição de tekoaxy (corpo imperfeito e mortal) e, assim, alcançar o estado de aguyje, isto é, perfeito e imortal, na Yvy Mara ẽy (Pissolato, 2007; Pierri, 2013). 
Algumas sequências demonstram estas questões. Por exemplo, na aldeia de Cantagalo, perto de Porto Alegre (RS), os realizadores encontram o senhor Augusto e dona Florentina Fernandes Paraí. O primeiro explica:

Tava, isso eu vou contar bem pra você. Os nossos antepassados, os Nhanderú Mirim, vieram do Paraguai, passando pela Argentina e pelo Brasil. Eles eram iluminados, semideuses. Eles alcançaram a Terra Sem Males, pra isso vieram do Paraguai. (...) Eles vieram construindo templos, Tavas. Eles esperaram, meditando pra alcançar a Terra Sem Males. E continuam passando nessa terra, e continuam construindo Tavas.

Neste momento, é importante esclarecer que vários Guarani advogam a existência de heróis míticos denominados kesuita, kechuíta, kerusu ou keiruçuita. Alguns antropólogos defendem que se trata de uma corruptela da palavra "jesuíta", mas os Mbya não consideram que aqueles fossem padres católicos, mas antes Nhanderu Mirim, antigos xamãs que teriam atingido a aguyje (Garlet, Assis, 2002; Litaiff, 2009). Ariel pergunta ao senhor Augusto e a dona Florentina se os jesuítas eram Nhanderu Mirim e ambos anuem. A última acrescenta que "[a]qui em Porto Alegre eles esperaram que Nhanderu os levasse. Foi aqui que eles apanharam o transporte para a Terra Sem Males." Por fim, dona Florentina esclarece que o propósito da construção da tava era deixar um símbolo para os Guarani saberem onde construir aldeias e viver: "Eles deixaram pra nós como símbolo. Pra nós chegarmos ali, construirmos aldeias, plantarmos... Mas agora os brancos estão se apossando de tudo." A ideia de tava como símbolo também aparece em alguns trabalhos etnográficos:

Onde foi caminhando o [Nhanderu Mirim] kechuíta, deixou a ruína, como um rasto
dele. Onde não botou a ruína, botou o nome na língua Guarani, por isso o lugar que
tem o nome na palavra Guarani é tudo lugar que o kechuíta viveu, porque era lugar
bom para viver, onde tinha mato bom, muito bichinho. Tudo isso é marca do kechuíta.
Por isso o Mbyá que quer seguir como Mbyá, como kechuíta, tem que pedir pro
Ñanderu prá descobrir o lugar bom (...) (Guarani Roque Timóteo apud Garlet, Assis,
2002: 103)
Como os Nhanderu Mirim eram muito inteligentes, eles já sabiam o que ia se passar
mais tarde com os Guarani, eles sabiam da invasão de nossas terras. Foi por isso que
eles construíram esta ruína, para marcar o caminho e lembrar a história dos Guarani.
(...) A ruína é como um documento, ela é a prova que mostra tudo o que era dos
Guarani. É por isso que Nhanderu Tenondegua enviou os Nhanderu Mirim para fazer
ruína, para mostrar nosso caminho, porque ele nos ama muito. (Guarani Tito Karai
apud Litaiff, 2009: 148, 150) A ideia de símbolo é apresentada nestas falas com dois propósitos que se sobrepõem. Em primeiro lugar, a tava é um sinal para os Guarani no sentido de saberem onde devem fazer aldeia, viverem uma vida alegre e, implicitamente, seguir a caminhada espiritual de aperfeiçoamento (aguyje) na direção da Terra sem Mal (Yvy Mara ẽy). Contudo, o último discurso parece propor que a tava também é um símbolo para os não 
indígenas reconhecerem e demarcarem o território Guarani, uma vez que Nhanderu já sabia da futura invasão dos jurua. Nesse sentido, é possível argumentar, como o dossier de registro do IPHAN (n.d.) defende, que os sinais dos deuses para os Mbya (principalmente os $\mathrm{karai}^{13}$ ) saberem onde devem construir as aldeias são normalmente invisíveis para os jurua, mas a tava de São Miguel é uma exceção devido à sua função adicional de elemento comprovativo para a demarcação das terras Guarani.

Mais tarde no filme, os realizadores visitam a aldeia Araponga, em Paraty (RJ), onde conversam com o karai Agostinho da Silva e a kunha karai ${ }^{14}$ Marciana debaixo de um alpendre de telha metálica e palha. A kunha karai traz de dentro da opy (casa de reza) uma moldura com uma foto da tava de São Miguel que comprou quando visitou o local nos anos 1990 e explica:

Não viemos até aqui só por querer, os nossos avós passaram por aqui. Alguma coisa nos leva até essas ruínas. Chegamos até lá porque eles querem que a gente chegue. Nhanderu Mirim deixou pra morarmos onde nossos avôs e avós morreram, pois até agora nós, os netos, continuamos vivos.

O karai acrescenta:

Eles [os jurua] acham que não foram os Guarani nem os Nhanderu Mirim que construíram isso. Eles falam: ah, só quando os portugueses vieram é que... construíram essas ruínas e agora os Guarani pensam que são deles, que podem morar nelas. Quando a gente estava lá, não queriam nem ver a gente. Mesmo vendendo nosso artesanato do lado de fora, os policiais ficavam ali, com as armas na mão. "Chegou a hora, vocês têm que ir embora", diziam. A gente juntava o nosso artesanato e ia dormir. Só depois de anos que alguns brancos perceberam que essa Tava foi deixada para nós por Nhanderu. Por isso agora apoiam mais o pessoal que mora lá. Não é mais como era antes, quando a gente morava lá.

Por fim, os realizadores visitam a aldeia Tamanduá, na Argentina, onde mora Dionísio Duarte Ortega, avô de Ariel. Este quadro encerra o ciclo de reflexão sobre a tava e introduz a dissensão no mundo Guarani, uma vez que aquele Mbya não considera que as ruínas sejam uma tava, mas, tal como vimos em Mokoi Tekoá, um palco de violência colonial:

Os jesuítas vieram ensinar aos Guarani e até os Karaís aceitavam. Alguns vieram e construíram essas ruínas bem perto das aldeias. Eles enganavam os Guarani e pegavam suas netas. Quem não se deixava ensinar, eles matavam. E os velhos que não prestavam para o trabalho eram mortos também. (...) Nos fizeram de bobos. É verdade! As ruínas estão lá mesmo. Mas se elas fossem realmente a Tava Mirim, os que construíram-nas estariam lá até hoje, e nos levariam para morar com eles. Mas

\footnotetext{
13 Pajé Mbya Guarani.

${ }^{14}$ Pajé Mbya Guarani do sexo feminino.
} 
quando vamos pra lá, só vemos um lugar vazio. Só vemos uma grande construção de pedra que recebe muitas visitas. É simplesmente o trabalho dos primeiros brancos que chegaram aqui. Eu não medito por ela, mas sim pelos antepassados que hoje estão lá em cima. (...) A Tava Mirim existe... Os Nhanderu Mirim, que alcançaram a Terra Sagrada, também. Mas não são as ruínas dos jesuítas. Aquilo é só uma coisa terrena. Os Nhanderu Mirim são coisas só nossas, esses nomes só devem ser usados por nós. Eles têm suas moradas no alto das florestas ancestrais, são várias as moradas dos Nhanderu Mirim. Nas margens dos grandes rios... Nesta terra que habitamos hoje, ninguém alcançou a Terra Sagrada ainda.

Em suma, e ecoando o trabalho de Harrison e Rose (2010) com as comunidades aborígenes mencionado no início do artigo, as ruínas devem ser compreendidas como um património dialógico que é construído através da participação de diversos atores, incluindo extra-humanos, como Nhanderu e Nhanderu Mirim, e que dobra o espaço e o tempo no sentido de construir o futuro (aguyje) a partir do passado. Nesse sentido, a categoria património é relevante para os Guarani, por um lado, como vimos em Mokoi Tekoá, enquanto contraplano da visualidade produzida pelo poder colonial e, por outro, na qualidade de recurso espiritual que permite a superação da condição perecível do corpo Mbya nesta terra imperfeita.

De um modo paralelo, é possível argumentar que, para os Guarani, a produção cinematográfica é relevante não só como instrumento de "shoot back" (Ginsburg, 1993), mas também enquanto prática na realização do belo caminho para a Yvy Mara ẽy. A conversa seguinte do realizador Ariel com o oficineiro Ernesto Carvalho inclui alguns indícios sobre esta questão:

Ariel: O trabalho com o vídeo vai se aprofundando. Eu estou sabendo que isso vai ser muito importante pro meu povo. Hoje eu me assustei quando eu vi as crianças ali, brincando. "Caramba, quantas crianças!” Tudo é pra eles. Não é pra mim. Cada vez mais a gente vai descobrindo coisas, e a importância delas.

Ernesto: Quando você fala "Não é pra mim", você está traduzindo aquela expressão Guarani que as pessoas falam quando vocês vão agradecer de modo especial alguma coisa, não é?

Ariel: Isso. Korupi Guara i ko (não é pra mim), Haeveté (obrigado) "Korupi Guaraiko". É isso. Esse trabalho Kovaeté Mbya Po Korupi Guaraiko. Não é pra mim, não é para esse plano.

Ernesto: Você acha então que o trabalho com vídeo não é pra esse plano?

Ariel: Porque existe outro plano. Existe um plano que não tem nome. Nem plano geral, nem plano fechado. É um plano sem plano. (apud Carvalho et al, 2011: 154, itálico meu)

Tendo em conta este contexto, a expressão "plano sem plano" é um termo inventado por Ariel para denominar a Yvy Mara ẽy (Terra sem Mal), isto é, um plano de existência em que tudo é imperecível, perfeito, belo e verdadeiro e onde, portanto, não 
ocorrem guerras entre planos e contraplanos. Nesse sentido, a producão filmográfica encontra ressonâncias nas práticas estético-éticas de convivialidade, comensalidade e corporalidade que têm como objetivo fomentar o bem viver e atingir a imortalidade na Terra sem Mal. Ou seja, o cinema é um meio de se ser iluminado. Um dos aspetos salientados por Ariel é que a produção de filmes fomentou o bem viver. Por um lado, através da corporalização cinematográfica do seu modo de ser que possibilitou o "encantamento" (Gell, 1998) da sociedade colonial, especialmente de São Miguel. Por outro, através da discussão interna sobre aspetos que causavam mais conflitos (como o consumo de álcool nas "festas brancas"). Além disso, apesar de não ser possível desenvolver aqui esta questão em extensão, a produção cinematográfica também encontra ressonâncias nas práticas xamânicas Mbya de procura de conhecimento dos deuses. Por exemplo, o nome Guarani e, portanto, o espírito (nhe’ê) de Ariel (Kuaray Poty) vem da morada de Nhamandu, deus do sol e da sabedoria, e o seu avô advogou que talvez fosse por isso que ele estava a realizar filmes sobre a tava.

Em suma, o que está aqui em causa em última instância para os Guarani, mas, idealmente, para todos nós, não é uma guerra de imagens entre planos e contraplanos. Enquanto os jurua lutam entre símbolos, isto é, entre objetivações da cultura e património, os Guarani caminham e pensam num outro plano (Yvy Mara ẽy) que, como Ariel explica, é "um plano sem plano".

\section{Bibliografia}

APPADURAI, Arjun. "Grassroots Globalization and the Research Imagination." Public Culture, v. 12, no 1, 2000, p. 1-19.

ASHWORTH, G. J.; TURNBRIDGE, J.. Dissonant Heritage: The Management of the Past as a Resource in Conflict. Chichester: Wiley, 1996.

ASHWORTH, G. J.; GRAHAM, Brian; TURNBRIDGE, J.. Pluralising Pasts. Heritage, Identity and Place in Multicultural Societies. London: Pluto Press, 2007

ASSIS, Valeria Soares. Dádiva, Mercadoria e Pessoa: As Trocas na Constituição do Mundo Social Mbyá-Guarani. Tese de Doutorado, Universidade Federal do Rio Grande do Sul, 2006.

AYDOS, Valéria. "A invenção do mito de Sepé Tiaraju na romaria da terra." Debates do $N E R$, v. $1, \mathrm{n}^{\circ} 5.2004$, p. 31-56.

BATISTA, Jean. Dossiê Missões. As Ruínas. Brasília: IBRAM, 2015. 
BAUER, Leticia. O Arquiteto e o Zelador: Patrimônio Cultural, História e Memória, São Miguel das Missões (1937-1950). Dissertação de mestrado, Universidade Federal do Rio Grande do Sul, 2006.

BELTING, Hans. Antropologia da Imagem. Lisboa: KKYM + EAUM, 2014.

BENETTI, Liliane, Jaz. João Loureiro, n.d., Disponível em: http://portal.iphan.gov.br/uploads/ckfinder/arquivos/jaz.pdf.

BIRD, Thomas. "Roland Joffé by Thomas Bird." Bomb, $\mathrm{n}^{\circ}$ 18, 1987. Disponível em: https://bombmagazine.org/articles/roland-joff\%C3\%A9/.

BRUM, Ceres Karam. 2007. "O mito de Sepé Tiaraju: etnografia de uma comemoração". Redes. Revista de Desenvolvimento Regional, v. 12 n 3. 2007, p. 5-20.

BYRNE, Denis. Counterheritage: Critical Perspetives on Heritage Conservation in Asia. New York, London: Routledge, 2014.

CALLADO, Antônio. Quarup. Mem Martins: Europa-América, 1973.

CARVALHO, Ana; CARVALHO, Ernesto Ignacio de; CARELLI, Vincent. Vídeo nas Aldeias. 25 Anos. Olinda: Vídeo nas Aldeias, 2011.

CESARINO, Pedro de Niemeyer. "Culturas múltiplas versus monocultura", Lugar Comum (UFRJ), nº 25-26. 2008, p. 271-283.

CHOAY, Françoise. Alegoria do Património. Lisboa: Edições 70, 2014.

CHUVA, Márcia. Os Arquitetos da Memória. Sociogênese das práticas de preservação do patrimônio cultural no Brasil (anos 1930-1940). Rio de Janeiro: Editora UFRJ, 2009.

CLASTRES, Hélène. The Land-Without-Evil. Tupi-Guarani Prophetism. Chicago: University of Illinois Press, 1995.

CUNHA, Manuela Carneiro da; CESARINO, Pedro de Niemeyer. Políticas Culturais e Povos Indígenas. São Paulo: Cultura Académica editora, 2014.

DALCIM, Ignacio. Fascínio e Mistério nas Ruínas das Missões. Passo Fundo: Berthier, 2010.

DEGER, Jennifer. Shimmering Screens: Making Media in an Aboriginal Community Minneapolis. London: University of Minnesota Press, 2006.

DICKS, Bella. Culture on Display: The Production of Contemporary Visitability. Maidenhead, Berkshire: Open University Press, 2003.

FOSTER, Hal. Vision and Visuality. Seattle: Bay Press, 1988.

GANSON, Barbara. The Guaraní under Spanish Rule in the Río de la Plata. Stanford: Stanford University Press, 2003.

GARLET, Ivori. Mobilidade Mbyá: História e significação. Dissertação de mestrado, Pontifícia Universidade Católica do Rio Grande do Sul, 1997.

GARLET, Ivori; ASSIS, Valéria S. de. "A Imagem do Kechuíta no Universo Mitológico dos Mbyá-Guarani.” Revista de História Regional 7(2). 2002, p. 99-114.

GELL, Alfred. Art and Agency. An Anthropology Theory. Oxford: Clarendon Press, 1998. 
GINSBURG, Faye. "Aboriginal Media and the Australian Imaginary". Public Culture vol. 5, nº 3, 1993, p. 557-578.

GONÇALVES, José Reginaldo Santos. A Retórica da Perda: os discursos do patrimônio cultural no Brasil. Rio de Janeiro: Editora UFRJ, 1996.

GRAHAM, Cunninghame R. B.. A vanished Arcadia; being some account of the Jesuits in Paraguay, 1607 to 1767. London: William Heinemann, 1901.

GRUZINSKI, Serge. Images at War. Mexico from Columbus to Blade Runner (14922019). Durham, London: Duke University Press, 2001.

HARRISON, Rodney. Heritage. Critical Approaches. Oxon, New York: Routledge, 2013.

HARRISON, Rodney; ROSE, Deborah. “Intagible Heritage.” In: BENTON, Tim (org.). Understanding Heritage and Memory. Manchester, New York: Manchester University Press, 2010, p. 238-276.

INGOLD, Tim. "Trazendo as coisas de volta à vida: emaranhados criativos num mundo de materiais". Horizontes Antropológicos, n 37, 2012, p. 25-44.

INSTITUTO SOCIOAMBIENTAL. "Xetá." n.d. Disponível em: https://pib.socioambiental.org/pt/povo/xeta/.

IPHAN. "Dossiê de Registro / IPHAN: TAVA - Lugar de Referência para os Guarani", n.d., Disponível em http://portal.iphan.gov.br/uploads/ckfinder/arquivos/Dossie_da_Tava_Lugar_de _Referencia_para_o_Povo_Guarani(1).pdf

KERN, Arno Alvarez. Utopia e Missões Jesuíticas. Porto Alegre: Editora da Universidade UFRGS, 1994.

KIRSHENBLATT-GIMBLETT, Barbara. Destination Culture. Tourism, Museums, and Heritage. Berkley: University of California Press, 1998.

LAFARGE, Paul. "Idealism and Materialism in the Conception of History." Socialist Standard, no 129, 1915.

LANGER, Erick; JACKSON, Robert H. The New Latin American Mission History. Lincoln: University of Nebraska Press, 1995.

LITAIFF, Aldo. “O ‘Kesuita' Guarani: Mitologia e Territorialidade.” Espaço Ameríndio, v. 3, nº 2, 2009, p. 42-160.

LUGON, Clovis. A República "Comunista" Cristã dos Guarani, 1610/1768. Rio de Janeiro: Paz e Terra, 1977.

MARCHI, Darlan de Mamann; SILVA, Juliano Borchardt da; DEZORDI, Estelamaris. "Patrimônio, turismo, práticas culturais e identidades na região das Missões no Rio Grande do Sul.” Revista Arqueológica Pública, v. 9, nº 11, 2015, p. 147-156.

MARCHI, Darlan de Mamann; COSTA, Luciana de Castro Neves. "From Ruins to Heritage of Humanity: Interfaces between Preservationist and Tourism Policies in São Miguel das Missões (RS).” In: HENRIQUES, Cláudia; MOREIRA, Maria Cristina; CÉSAR, Pedro Bittencourt (orgs.). Tourism and History. World Heritage 
- Case Studies of Ibero-American Space. Braga: Interdisciplinary Centre of Social Sciences - University of Minho (CICS.NOVA.UMinho), 2016.

MEIRA, Ana Lúcia Goelzer. O patrimônio histórico e artístico nacional no Rio Grande do Sul no século XX: atribuição de valores e critérios de intervenção. Tese de Doutorado, Universidade Federal do Rio Grande do Sul, 2008.

MIGNOLO, Walter. Local Histories/Global Designs: Coloniality, Subaltern Knowledges, and Border Thinking. Princeton, Oxford: Princeton University Press, 2012.

MITCHELL, W. J. T.. Iconology: Image, Text, Ideology. Chicago, London: The University of Chicago Press, 1986.

MONTESQUIEU. O Espírito das Leis. São Paulo: Martim Fontes, 2000.

MORAES, Carlos Eduardo Neves. A Refiguração da Tava Miri São Miguel na Memória Coletiva dos Mbyá-Guarani nas Missões/RS, Brasil. Tese de Doutorado: Universidade Federal do Rio Grande do Sul, 2010.

MORAES, Tobias Vilhena de. Preservação Arqueológica e Ação Educativa nas Missões. Tese de Doutorado, Universidade Federal do Rio Grande do Sul, 2014.

MIRZOEFF, Nicholas. The Right to Look: A Counterhistory of Visuality. Durham, London: Duke University Press, 2011.

NEUMANN, Eduardo. "Fronteira e identidade: confrontos luso-guarani na Banda Oriental 1680- 1757." Revista Complutense de Historia de América, n 26, 2000, p. $73-92$.

"A lança e as cartas: escrita indígena e conflito nas reduções do Paraguaiséculo XVIII." História Unisinos, v. 11, n 2, 2007, p. 160- 172.

OVERING, Joana; PASSES, Alan. The Anthropology of Love and Anger. The Aesthetics of Conviviality in Native Amazonia. London, New York: Routledge, 2000.

PIERRI, Daniel. O perecível e o imperecível: lógica do sensível e corporalidade guaranimbyá. Dissertação de mestrado, Universidade de São Paulo, 2013.

PISSOLATO, E. de P.. A duração da pessoa: mobilidade, parentesco e xamanismo Mbya (Guarani). São Paulo: Editora da Unesp, 2007.

REPÚBLICA FEDERATIVA DO BRASIL. "Nomination of the World Heritage List Submitted by the Federal Republic of Brazil São Miguel das Missões", 1982.

RIEGL, Aloïs. O Culto Moderno dos Monumentos. Lisboa: Edições 70, 2013.

SAMUEL, Raphael. Theatres of Memory. Past and Present in Contemporary Culture. London, Brooklyn: Verso, 2012.

SANTOS, Júlio Ricardo Quevedo dos. "Romaria do Caaró: Prática Cultural, Património e Discurso Midiático." LEAL, Elisabete; PAIVA, Odair da Cruz (org.). Patrimônio e História. Londrina: Unifil, 2014, p. 97-112.

SARREAL, Julia J.S.. The Guarani and their Missions. A Socioeconomic History. Stanford: Stanford University Press, 2014.

SCHADEN, Egon. Aspetos Fundamentais da Cultura Guarani. São Paulo: Editora da Universidade USP, 1974. 
SILVEIRA, Flávio Leonel Abreu da. As paisagens fantásticas e o barroquismo das imagens. Estudo da memória coletiva de contadores de causos da região missioneira do Rio Grande do Sul. Tese de Doutorado, Universidade Federal do Rio Grande do Sul, 2004.

SMITH, Laurajane. Uses of Heritage. Oxon: Routledge, 2006.

SMITH, Laurajane; AKAGAWA, Natsuko. Intangible Heritage. London, New York: Routledge, 2009.

SOARES, André Luís R.. Organização Sócio-Política Guarani: Aportes para a Investigação Arqueológica. Dissertação de Mestrado, Pontifícia Universidade Católica do Rio Grande do Sul, 1996.

SOUZA, José Otávio de Catafesto. Aos Fantasmas das Brenhas: Etnografia, invisibilidade e etnicidade de alteridades originárias no sul do Brasil. Tese de doutoramento, Universidade Federal de Rio Grande do Sul, 1998.

--. "O sistema econômico nas sociedades indígenas guarani pré-coloniais." Horizontes Antropológicos, $\mathrm{n}^{\mathrm{o}}$ 18, 2002, p. 211- 253.

STELLO, Vladimir. Além das Reduções: A Paisagem Cultural da Região Missioneira. Tese de Doutorado, Universidade Federal do Rio Grande do Sul, 2013.

VIDAL, Belén. Heritage Film. Nation, Genre and Representation. New York, Chichester, West Sussex: Columbia University Press, 2012.

VIVEIROS DE CASTRO, Eduardo. Metafísicas Canibais. São Paulo: Cosac Naify, 2015.

VOLTAIRE. Cândido ou O Otimismo. Lisboa: Relógio D’Água, 2016.

WATERTON, Emma; WATSON, Steve. Culture, Heritage and Representation. Perspetives on Visuality and the Past. London, New York: Routledge, 2016.

\section{Filmografia}

Mokoi Tekoá Petei Jeguatá, Duas aldeias, Uma caminhada. [longa-metragem]. Dir. Jorge Ramos Morinico/Germano Beñites/Ariel Duarte Ortega. Vídeo nas Aldeias. Brasil, 2008. 63 mins.

República Guarani. [longa-metragem]. Dir. Sylvio Back. Embrafilme - Empresa Brasileira de Filmes/ Sylvio Back Produções Cinematográficas, 1981. 100 mins.

Tava, A Casa de Pedra. [longa-metragem]. Dir. Patrícia Ferreira (Keretxu)/Ariel Duarte Ortega/Ernesto Ignácio de Carvalho/Vincent Carelli. Vídeo nas Aldeias. Brasil, 2012. 78 mins.

The Mission. [longa-metragem]. Dir. Roland Joffé. Warner Bros./Goldcrest Films International/Kingsmere Productions/Enigma Productions/AMLF. Reino Unido, France, 1986. 125 mins.

Xetá na Serra dos Dourados. [curta-metragem]. Dir. José Loureiro Fernandes. Instituto de Pesquisas da Faculdade de Filosofia da Universidade Federal do Paraná. Brasil, 1959. 46 mins. 